\title{
Electoral Donations as Legal Bribes: Evidence from a Survey of Private Corporations in Colombia
}

\author{
Nubia Evertsson
}

\author{
Department of Criminology, Stockholm University, Universitetsvägen 10C, 10691 Stockholm, Sweden
}

\begin{abstract}
In this article I study why companies give electoral donations to support political leaders. I collected and used a unique data set on electoral financing at the corporate level in Colombia. The data show that firms consider electoral contributions to be 'legal bribes'. Consistent with the theory of bribery, these donations are made because of the low quality of election regulation, the high expectation of reciprocity, and the pre-existing relationships with incumbents. These features suggest 'legal neutralization': donors can break the law without committing crime.
\end{abstract}

Keywords: Electoral financing, legal bribes, law neutralization.

\section{INTRODUCTION}

To use the letter of the law to defeat its spirit, and to do so with impunity, has become a notorious form of white-collar crime among business leaders (McBarnet 2006: 1091-1092). In this article, I explore a case in point: legal electoral donations by private corporations.

Campaign contributions are instruments of political participation by endowment. In most countries where elections are privately funded, the electoral authorities regulate this practice in order to ban donations from companies that have pre-existing relationships with recipients (Nassmacher 2003). Legislators believe that this suffices to remove the obligation of reciprocity from incumbents. In practice, however, electoral donors are compensated when political leaders are in office (Della Porta and Vannucci 1999; Harstad and Svensson 2011; Rose-Ackerman 1999). When this occurs, an electoral donation in effect becomes a 'legal bribe' (Friedrichs 2004: 134); although such donations are legal, they can provide the donor with undue influence on political decisions and outcomes.

As Becker (1968) has stipulated, crimes can be originated in legal and illegal actions. The development of this theory in the case of political corruption (RoseAckerman 1977; 1999) provides the basis for exploring electoral funding as a mechanism that brings influence to bear on incumbent governments. A number of studies have examined the impact of private campaign financing on policy outcomes and the strategic approaches used by companies to deliver these

*Address corresponding to this author at the Department of Criminology, Stockholm University, Universitetsvägen 10C, 10691 Stockholm, Sweden;

Tel: +46-738222843; Fax: +46-8157881;

E-mail: nubia.evertsson@criminology.su.se resources to politicians ${ }^{1}$. The caution showed by early scholars to avoid using criminal labels was, however, challenged by Harstad and Svensson (2011), who undertook a theoretical path that provides more specification. Harstad and Svensson claimed that the influence exercised over policy outcomes is the result of using electoral donations and lobbying ${ }^{2}$ as kinds of bribery in developing nations, or as substitutes for bribery in developed nations. A few studies have explored this relationship empirically in the case of lobbying, but no investigation has been conducted in the case of electoral donations.

Here I collect and analyze a unique data set on political corruption and electoral campaign financing at the corporate level in Colombia, aiming at understanding why firms use this mechanism. The analysis of data collected reveals that private corporations see electoral donations as 'legal bribes', a view that coincides with the characterization made of their relationship with incumbents. This suggests 'law neutralization' (McBarnet 2006): illegal behaviors can be hidden and legalized by the law.

\section{THEORETICAL APPROACH}

Scholars have sought to make sense of the role of money in politics. Different theories have been used to

\footnotetext{
${ }^{1}$ See Stratmann (2005) and Smith (1995) for a review of the literature on campaign financing.

${ }^{2}$ For convenience, Harstad and Svensson (2011: 46) used the term lobbying to name campaign contributions. With the term lobbying they also denote other means of influence-buying; however, Harstad and Svensson did not provide more specification. It should be noted that lobbying and campaign contributions are not one and the same. Although both constitute methods of influencebuying, campaign contributions imply the delivery of money, while lobbying does not. This does not mean that political lobbyists do not deliver campaign contributions; they often do. Lobbying is the action of persuading or trying to influence politicians or the government to change the law. Campaign financing is the delivery of money and in-kind support to candidates who are competing for public office, with the purpose of changing the law.
} 
understand how donor corporations make use of legal mechanisms such as electoral donations and lobbying. Scholarship contributions are diverse, as the literature presents different approaches. In the pioneering contribution of Grossman and Helpman (1994), it was argued that electoral donations can influence the decisions of policymakers, because companies give electoral contributions to redirect government policies and services for their own benefit ${ }^{3}$. Other studies that use this approach have reported that electoral donations are used to shape the legislative agenda (Apollonio and La Raja 2004) and influence the way bills are voted on in Congress (Stratmann 1992; Hart 2001). In other cases it has been demonstrated that electoral donations are used to improve the competitiveness of donors by neutralizing the impact that donations from the competition may have (Hersch and McDougall 2005), reducing governmental control over the companies' activities (Gordon 2001), and guaranteeing contracts with governmental agencies (Zullo 2006). The strategic rationality of donors has also been analyzed from the point of view of timing and approaching. Zullo (2006) has found that companies give contributions between elections to guarantee the visibility of their donations, while Stratmann (1998) has reported that to avoid unreliable legislators, some companies time their donations to coincide with key legislative events.

Other scholars have studied the interaction between money, information, and access to legislators. AustenSmith (1996) has argued that legislators have the monopoly on time and legislative decisions, so to maximize their legislative decision-making process, legislators must balance the granting of access to acquire information with the receiving of campaign contributions. Legislators are aware that too much access to contributors will have negative consequences for the quality of the legislator's decisions, while too much access to informative lobbyists will undermine the financial status quo of the legislator. In other studies the approach has been limited to the issue of signaling. Ball (1995) has argued that contributions induce distortions because of the signaling inducement of this kind of resource. Lohmann (1995) has claimed that campaign contributions are used to signal independent preferences at relatively small cost in relation to the policy payoffs. Hall and

\footnotetext{
${ }^{3}$ The drawback to Grossman and Helpman's (1994) theory is that they fail to specify the types of resources given to politicians. There is no clarification of whether money comes in the form of electoral donations, lobbying or bribes. Nonetheless, they acknowledge that policymakers can be influenced by such payments.
}

Deardorff (2006) have approached signaling as a mechanism used to make lobbyists and legislators natural allies on coincident issues. The main argument is that contributions delivered by lobbyists are not used to change legislators' minds, but as a subsidy of the legislative function. They have highlighted the two ethical paradoxes of their model. First, equality cannot be guaranteed, because only groups that have sufficient resources achieve access. Second, the ethics of the legislator cannot be guaranteed, because it is difficult to discern why one should pay extra money to legislators for the work they supposed to do.

Previous theoretical work on the impact that money has on politics tends to gloss over the conceptual distinction between campaign financing and illegal forms such as bribery. A recent contribution by Harstad and Svensson (2011) has presented a straightforward relationship between these concepts. Harstad and Svensson's basic assumption is that campaign financing in developed nations is a substitute for bribery, because when companies seek permanent changes to government regulations they make electoral contributions. When giving bribes, however, companies face constant uncertainty. Bribery becomes extortive and expensive, because once a company has paid a bribe and wants to avoid the bureaucrats reneging, it is forced to pay all over again. This is increasingly costly, because companies do not continue to deal with the same officials. Given that companies would prefer to have permanent changes to official regulations with less cost, campaign contributions can help them to achieve this purpose ${ }^{4}$. However, Harstad and Svensson have assumed that when a country's level of development is low, bribes that are too large serve to discourage campaign financing, because companies are caught in a poverty trap by a never-ending cycle of bribery. In this scenario, private investors are unable to achieve influence through campaign financing, because the government announces stable regulations and less red tape in order to stimulate investment and promote development. As a consequence, bribery is the only available alternative if one is intent on bending the rules. This leaves the ongoing, legitimate, private funding of elections in developing nations as a kind of bribe.

\section{Bribes and Legal Bribes}

Bribery is the most common practice associated with political corruption. In Harstad and Svensson

${ }^{4}$ Lobbying, for example, is another alternative. 
(2011: 46) bribery is defined as 'an attempt to bend or get around existing rules or policies'. In this article I adopt the same definition. According to Harstad and Svensson, bribery is an illegal and unregulated practice that has a specific and short-term effect on the performance of the firm. What makes bribery and campaign financing similar is that both aim to achieve undue influence. For Harstad and Svensson, electoral donations are legal and regulated practices that seek a long-lasting effect by means of 'changing existing rules or policies' (2011: 46). The paradox of electoral donations is that this legal and regulated practice brings about undue influence on incumbents.

Friedrichs introduced the concept 'legal bribe' to denote that the financing of elections and legislative lobbying induces the delivery of undue benefits, and therefore it promotes corruption. Friedrichs (2004: 136) argues that electoral donations are 'legal bribes' because they are 'a mechanism used to promote issues not candidates'. Here I use the term 'legal bribe'-as introduced by Friedrichs-to denote the undue influence achieved by electoral donors. Note that, although the term 'legal bribe' was not used by Harstad and Svensson, Friedrichs definition of 'legal bribe' concurs with Harstad and Svensson's definition of campaign financing.

According to Lambsdorff (2008) bribes are given when there are: (1) pre-existing labor or social links between companies and political leaders, because this guarantees there will be no opportunistic behavior; (2) the possibility of spelling out expectations of reciprocity at the moment of delivery, because this increases predictability for recipients; and (3) a weak regulatory framework that is not capable of detecting or sanctioning irregular behavior, because of a lack of institutional capacity and/or legal mechanisms to make the law enforceable.

\section{PREVIOUS RESEARCH AND RESEARCH QUESTIONS}

The theoretical argument introduced by Harstad and Svensson (2011) has been tested in a limited number of empirical studies on lobbying, but there are no investigations that use data on electoral donations. The contributions of Bennedsen et al. (2011) and Campos and Giovannoni (2007) focused on studying the delivery of money in the form of lobbying, based on empirical secondary material collected in economic studies conducted by international organizations. In particular, Bennedsen et al. (2011) used the 1998 World Business Environment Survey (WEBS) conducted by the World Bank in 80 countries, while Campos and Giovannoni (2007) used the 2002 Business Environment and Enterprise Performance Survey (BEEPS) conducted in 25 countries by the European Bank for Reconstruction and Development and the World Bank. Bennedsen et al. (2011) found that stronger companies-larger, older, exporting, government owned, and with fewer competitors-pay fewer bribes, because these firms have more political influence achieved through lobbying. Among weak firms the prevalence of bribery is higher, and it is used to increase their competitiveness and mitigate government intervention. They also observed that when companies have credibility in the legislative system, firms invest in lobbying rather than bribery, which indicates rule-changing rather than rulebreaking, as suggested by Harstad and Svensson (2011). Similar results were obtained by Campos and Giovannoni (2007). They particularly showed that large and foreign-owned firms joint lobbying groups aimed at achieving influence, because this has an economically meaningful effect. They reported that firms located in the capital city are more likely to enter a lobbying group for the same reason. Political stability increases the preferences of the firms to enter lobbying groups. Finally, they reported that becoming a member of a lobby group is associated with the level of development, as suggested by Harstad and Svensson (2011). In this sense they concluded that lobbying and corruption are substitutes for each other.

These remarkable and thoughtful findings have some limitations, mainly related to the data sources. First, the data captured in WEBS and BEEPS do not provide information that speaks directly to the concepts studied. In particular, Bennedsen et al. (2011) used a broad measurement of political influence across different types of political and bureaucratic actors as a proxy for lobbying ${ }^{5}$, while Campos and Giovannoni (2007) used trade union membership to measure lobbying. Both Bennedsen et al. and Campos and Giovannoni extended their conclusions on lobbying to campaign financing. However, in the case of Bennedsen et al. (2011), the authors are not allow for the fact that influence over regulations can be achieved by other legal and illegal means, and so as a measure of lobbying activity it can lead to over-estimations of the practice; meanwhile, Campos and Giovannoni (2007) did not take into account that lobbying can be a more

\footnotetext{
${ }^{5}$ The original wording of the question used by Bennedsen et al. (2011: 4) is What is the extent of the influence of firms on $X$ [where $X$ is government executive, legislature, ministry, and regulatory agency]?
} 
extended practice when it is hired directly by the companies, a fact that can lead to under-estimations of this variable. Second, these studies did not present information on the noise introduced to the data because of the contentious nature of the topics studied. Third, in the case of the data used by Campos and Giovannoni (2007), there were not sufficient theoretical explanations to provide a convincing argument that trade union membership-used as a proxy of lobbying -is the same as bribery. Fourth, although the data used by Bennedsen et al. (2011) included a sample of developed and developing countries, they did not report any particular differences respecting the behavior of firms, as was suggested by Harstad and Svensson (2011).

To avoid these limitations, and to have more precision about the types of resources delivered by private corporations, I collect and use a unique data set on electoral donations in Colombia, with a view to answer: Why do companies make electoral donations? Here I do not analyze lobbying-in contrast to Bennedsen et al. (2011) and Campos and Giovannoni (2007) - but focus on studying electoral donations.

\section{WHY COLOMBIA?}

Scholars have argued that longer periods of exposure to democracy reduce corruption (Treisman 2000; Sung 2004). However, although Colombia is the oldest democracy in Latin America (Deas 1993) ${ }^{6}$, corruption is one of the greatest concerns of that country. Therefore, it can be expected that corruption has also affected the practice of funding elections there. Indeed, according to the World Economic Forum (2006) the impact that electoral donations have on policy outcomes in Colombia is one of the greatest in the world. Colombia ranks 115 of the 125 countries studied by this organization (country mean 3.2, Cl 2.83.6, on a scale of 1 to 7 where 7 was little influence). This paradox makes Colombia an interesting case to study ${ }^{7}$.

\section{The Electoral Funding System in Colombia}

Elections in Colombia were privately financed until 1990, when the new political constitution-adopted

\footnotetext{
${ }^{6}$ In Colombia elections have been held regularly since its independence from Spain in 1819, except for a short period of military rule between 1954 and 1957.

${ }^{7}$ In another 29 countries, similar election funding systems and levels of influence on policy outcomes and corruption were observed. Those countries are Albania, Bosnia and Herzegovina, Bulgaria, Croatia, Czech Republic, Georgia, Hungary, Italy, Kazakhstan, Latvia, FYR Macedonia, Moldova, Romania, Slovakia, Argentina, Brazil, Dominican Republic, El Salvador, Guatemala, Jamaica, Mexico, Panama, Peru, Trinidad and Tobago, Indonesia, Sri Lanka, Thailand, Mali, and Zambia.
}

after the peace agreement with the guerrilla group $\mathrm{M}$ 19-established that the State had the obligation to fund electoral campaigns. The purpose of this rule was to guarantee equality among old and new contenders. Law 134/1994-which developed this constitutional mandate-stipulates that elections can be funded using a mixed system: public funds, private funds, and bank/personal loans.

In Colombia, public funds are given through direct subsidies and indirect mechanisms. Subsidies are distributed using a hybrid formula that combines equitable distribution and electoral strength, and they are disbursed before and after the election. The first disbursement, 10 per cent of the maximum expenditure allowed, is granted at the starting point of the electoral campaign period to guarantee egalitarian competition. After the election, the second reimbursement is distributed, proportional to vote obtained; this payment applies only to those candidates that reach a threshold of five percent of voter support. To receive the second reimbursement, candidates must submit their campaign's financial statements. In any case, the amounts reimbursed exceed the total amount used in the campaign. The reimbursement of public funds is done through the political parties. Indirect public funding is granted in the form of reduced postal rates and timeslots on public radio and television broadcasting.

Regarding private funding, electoral donations can be given in cash and in kind to candidates and/or political parties. For each election, the National Electoral Council is responsible for establishing the ceilings on individual contributions, and the total expenditures allowed for campaigning. Foreign donations, and contributions from state offices, state contractors, and the candidate/candidate's family members, are prohibited. Corporate donations must be approved by the board of directors of the firm. Donations can be made for a limited period, starting three months before the election day. Candidates are responsible for registering the contributions they receive, and for the funding and administration of their own campaigns. In a few instances parties grant contributions to certain candidates.

\section{METHOD}

\section{Research Design and Data Collected}

The data used in this article are taken from the 2009 survey on election financing in Colombia, which I 
directed on behalf of the Department of Criminology, Stockholm University. The fieldwork was conducted by Gallup Colombia between April and July 2009. The main purpose of the survey was to collect data at the company level about electoral campaign financing and political corruption. The information was collected by means of personal interviews carried out at the informants' offices. Each interview lasted an average 43 minutes. The main questionnaire contained 79 questions (224 entries) ${ }^{8}$. I designed the questionnaire in English to facilitate internal discussions with colleagues during the preparation stage, and then I translated it into Spanish for the application of the fieldwork in Colombia.

The survey included data on non-donor and donor companies for the 2006-2007 elections of the president, congress, and local authorities in Colombia. The sampling frame for non-donors was taken from the National Chamber of Commerce $(N=147,617)$, while in the case of donors it was provided by the National Electoral Council $(\mathrm{N}=1,849)^{9}$. To avoid duplications in the sampling frame, companies in the donor group were removed from the general lists of companies. The sample size was 300 companies, of which 50 per cent were donors and 50 per cent non-donors. The surveys were conducted in the country's capital, Bogotá, and the cities of Medellín, Barranquilla, Cali, and Bucaramanga. These cities account for 92 per cent of national economic activity (Departamento Nacional de Planeación 2009). Bearing in mind the characteristics of the study, it was decided that the companies surveyed should meet a certain profile: an informant was to be located at the headquarters of the company concerned; the informant should be the legal representative of the organization (general manager, CEO, or owner); and the state should not be a shareholder in the company. These provisions were prompted by the fact that board members are responsible for decisions to donate to electoral campaigns in Colombia, while companies with any state ownership were excluded from the sample, because they are prohibited by law from making donations to political campaigns.

In order to select respondents, a stratified systematic sampling method was employed for each

\footnotetext{
${ }^{8}$ The questionnaire was evaluated in five workshops that were held in the months of February and March 2009. In addition, a pilot test was conducted of six companies located in Bogotá, Medellín, and Cali (two pilot surveys per city). ${ }^{9}$ It is possible that some companies made donations, but they were not registered in the reports submitted by the candidates to the electoral authority. However, it is not known in what percentage this may have taken place.
}

city and list of donors and non-donors. Both lists were first classified by the size of the company (determined by the number of employees) and then sorted into alphabetic order. To guarantee that the sample accurately reflected the organizations' relative sizes, it was decided that when a chosen company failed to answer the phone, did not meet the required profile, or refused to participate in the survey, then the next company on the list would be contacted, to ensure that the substitute company would be of a similar size to the company it replaced ${ }^{10}$. There were 18 companies that could not be reached because they did not answer the phone, 21 companies that did not meet the desired profile, and 51 companies that refused to participate because of the subject of the survey. Detailed information about these companies is presented in Appendix A. It is worth noting that more non-donors than donors were replaced during the fieldwork (59 and 31 companies, respectively). Under such circumstances, selection bias is an obvious concern. To assess the situation, I compared unreplaced companies with replaced companies. In Appendix B, I present a set of regressions using the observable Company size as dependent variable in relation to the reasons for replacement. Companies that were not replaced are reported in row one, followed in consecutive rows by the companies that were replaced. The regressor is a dummy variable taking the value of one, if the company was not replaced (for regression in the first row), or if the company was replaced because of any of the five reasons given above (for regressions in rows two to six). The ordinary least squares (OLS) regressions showed that there was no evidence to suggest that the sample of replaced companies is different in terms of size from the sample of unreplaced companies. This indicates that the replaced sample has the same size characteristics as the unreplaced sample. Therefore, there was no observable evidence of selection bias.

Given the sensitivity of the topic, different strategies were adopted to reduce possible reticence among the respondents. Researchers have estimated that in surveys that address sensitive issues there is a tendency of underreporting of between 10 per cent and 45 per cent of responses, which can lead to serious interpretation errors (Lensvelt-Mulders et al. 2005: 337). As a means of reducing levels of reticence in

\footnotetext{
${ }^{10}$ In the literature, company size has been reported as a control characteristic (Bennedsen et al. 2011; Campos and Giovannoni 2007). This does not mean that all companies have the same profile, however.
} 
surveys on corruption, Svensson (2003: 212-213) has proposed the following measures: placing questions related to corruption at the end of the questionnaire, so that they are only answered once credibility and trust have been established; including control questions in different sections of the questionnaire to enhance data reliability; and contracting out the fieldwork to a prestigious local company. These measures were all employed in the present study. In addition, I also used the methodology suggested by Azfar and Murrell (2009), to identify reticence. These researchers have proposed a two-stage, randomized response method to identify reticent respondents in surveys on sensitive issues. The method is based on a set of ten questions towards the end of the questionnaire (seven of which are more critical than the other three) that require the respondent to toss a coin and then say yes, if the coin comes up heads or if he or she has ever engaged in the behavior in question. If the respondent says no seven consecutive times, this person can be classified as reticent, and hence his or her answers should be excluded from the study (for details, see Azfar and Murrell 2009: 393). This method assumes that the probability of getting seven consecutive heads is minuscule (1/128 or 0.8 per cent), and it can therefore be assumed that the informant has lied. Azfar and Murrell suggested that informants not classified as reticent should be called 'supposedly reliable', since it may not be possible to assert that all those who are unforthcoming have been detected by this method. After the fieldwork was completed, the answers to the question included to identify reticence were studied. The analysis revealed that 28 per cent of respondents were reticent ${ }^{11}$. This means that 84 respondents had probably lied, of which half were donors. To enhance the reliability of the data, these respondents' questionnaires were removed from the analysis. Finally, the sample on which the results of this article are based corresponds to 218 surveys that can be labeled 'supposedly reliable', of which 50 per cent came from donors and 50 per cent from non-donors.

\section{Variables and Model Specification}

Central to the analysis are the data on campaign finance, called Status in the statistical model.

\footnotetext{
${ }^{11} \mathrm{~A}$ reticent rate of 28 per cent is considered normal for surveys on corruption. Clausen et al. (2011: 446) have observed that in surveys that focus only on corruption, reticence is higher (about 33 per cent) than in general surveys where questions about corruption are the minority (about 13 per cent). In general surveys, respondents answer more candidly, because they do not feel they are being judged, while in surveys on corruption, respondents feel questioned, which increases the probability that they will attempt to hide irregular behavior.
}

Companies were asked whether they had made donations to political campaigns in the last election period in Colombia (2006-2007). Their answers were coded into two categories. In the first category were non-donors, those companies that had not contributed to political campaigns. In the second category were donors, those companies that had made contributions to political campaigns.

To explain the behavior of these companies, I included in the analysis a set of variables supported on two conceptual approaches to bribery. First, based on Harstad and Svensson (2011) I explored the profile that campaign contributions have for the surveyed companies. In particular, I evaluated whether campaign contributions are considered as Bribe substitute or Legal bribes, or as Additional cost-the questions employed to obtain information on these variables are presented in Appendix C. Second, I wanted to determine if the factors identified by Lambsdorff (2008) as determinant for bribery also can explain the delivery of electoral donations. I obtained information on Previous relationships between donors and incumbents, Expected reciprocity from incumbents and Regulatory quality, as described in Appendix C.

Finally, I included a set of control variables to increase confidence in the results, given that regression analyses are vulnerable to omitted variables bias. I used Company size and Age of the company (year of creation), which have been identified as control variables in previous studies. According to Campos and Giovannoni (2007) and Bennedsen et al. (2011), company size and age are determinants when a company has to decide whether or not to get involved, either in campaign financing and lobbying or in bribery ${ }^{12}$.

\section{Recodification}

The analysis of the data revealed a potential problem of quasi-separation, which is usually described as numerical coincidence. According to Hosmer and Lemeshow (2002: 135), quasi-complete separation is caused by the structures in the data. The univariable analysis of the variable Regulatory quality showed that the category five answer, which corresponds to 'very high quality', received only three observations (data not shown, but available on request). The bivariable analysis of the dependent variable Status and the

\footnotetext{
${ }^{12}$ Campos and Giovannoni (2007: 13) also referred to studies by Hellman and Kauffman (2003) and Solanko (2003).
} 
independent variables showed cells with fewer than five observations for the variable Regulatory quality, and also for the variable Expected reciprocity (data not shown, but available on request). The potential problem of quasi-separation was confirmed, when performing a logistic regression. To address this issue, Hosmer and Lemeshow (2002: 138) suggested removing the variable in question or recoding the answer categories of the variables with problems. Here I adopted the second alternative, because the theoretical framework indicates the possible existence of relationships between these concepts; therefore, the removal of the variables was not a viable alternative. While I am aware that the transformation of the ordinal variables entails a costly loss of information-and that this can be a motive of critique-it was necessary to address the quasi-complete separation of the data.

To avoid adopting an arbitrary recodification scale, I examined the variations of the classification accuracy of two models containing dummy variables obtained by two different aggregation procedures. In the first alternative, the value 0 was assigned for answers in categories one and two, and the value 1 was given for answers in categories three, four, and five. In the second alternative the value 0 was assigned for answers in categories one, two, and three, and the value 1 was given for answers in categories four and five. The results (given in Appendix D) suggest that the second alternative gave a better performance, since the classification accuracy of the model obtained was higher than in the first alternative $(67.2 \%$ and $63.6 \%$, respectively). This implies that the recodification procedure of the likert scales that should be used in the statistical analysis assigns 1 to answers four and five, and 0 otherwise (where 1 denotes agreement with the concept evaluated, see Appendix C). Appendix E gives the descriptive statistics, and Appendix $F$ the pair-wise correlation coefficients.

The variable company size was recoded as dummy variable using the classification of the International Chamber of Commerce, as follows: Small-sized companies have fewer than 49 employees, Mediumsized companies have between 50 and 249 employees, and Large-sized companies have more than 250 employees. This permits international comparisons with Campos and Giovannoni (2007) and Bennedsen et al. (2011).

\section{RESULTS}

Table 1 shows a series of logistic regressions corresponding to the payment of electoral donations.
Model 1 reports the baseline regression, which includes the control measurements, in line with Campos and Giovannoni (2007) and Bennedsen et al. (2011). Results indicate that Medium-sized companies and Old companies are more likely to be electoral donors. These outcomes provide a specific profile for electoral donors comparable to the characteristics identified by other scholars for lobbyists and bribers ${ }^{13}$.

In Model 2 I study the role of electoral donations. I evaluate the variables Bribe substitute, Legal bribe, and Additional cost. Results indicate that Bribe substitute and Additional cost have higher p-values, in contrast to Legal bribe. This suggests that Legal bribe can-at least partially for the moment-be used to explain the delivery of electoral donations among the firms surveyed ${ }^{14}$. Although some collinearity is expected between the variables Bribe substitute and Legal bribe with the regressor Additional $\operatorname{cost}^{15}$, the pair-wise correlation coefficients show in Appendix $F$ revealed no collinearity between them. In fact, the correlation between Bribe substitute and Legal bribe is 0.024; between Bribe substitute and Additional cost it is 0.010; and between Legal bribe and Additional cost it is 0.153 . These results show that in the case of electoral donations such payments are not considered an additional cost for the companies concerned, but nonetheless electoral donations made by a small number of companies do indeed constitute an additional cost, although they fail to recognize it. Although the survey data do not provide evidence to explain why this happens, it can probably be assumed that when companies make voluntary contributions to political campaigns, they can officially register and report their payments to the electoral authorities. Thus, the possibility of legal registration neutralizes the connotations of the election contribution being an additional payment.

Regarding the reasons for making electoral donations, in Model 3 I examine whether the motives for bribery apply here-Expected reciprocity, Previous relationship and Regulatory quality. The results show that the variables studied in Model 3 contribute to explaining the behavior of the companies surveyed-

\footnotetext{
${ }^{13}$ Large and older companies are usually involved in lobbying (Bennedsen et al. 2011), while smaller and recently created companies more often pay bribes (Campos and Giovannoni 2007).

${ }^{14}$ Observe that this not means causality.

${ }^{15}$ According to Lambsdorff (2008) bribes result in additional costs for companies, because they do not correspond to standard or conventional payments.
} 
Table 1: Summary of Logistic Regression Models

\begin{tabular}{|c|c|c|c|c|c|}
\hline Independent variables & Model 1 & Model 2 & Model 3 & Model 4 & Model $5^{b}$ \\
\hline Age of the company & ${ }^{*} 0.021$ & ${ }^{*} 0.023$ & ${ }^{* *} 0.030$ & **0.029 & ${ }^{* *} 0.035$ \\
\hline Small-sized company ${ }^{a}$ & 0.178 & & & & \\
\hline Medium-sized company ${ }^{a}$ & $* * 1.175$ & $* * * 1.209$ & $* * 1.122$ & $* * 1.125$ & $* * 1.141$ \\
\hline Bribe substitute (SB) & & 0.061 & & & \\
\hline Legal bribe (LB) & & $* * * 1.244$ & $* * * 1.160$ & 0.358 & $* * * 1.182$ \\
\hline Additional cost (AC) & & 0.240 & & & \\
\hline Expected reciprocity (ER) & & & ${ }^{*} 0.804$ & 0.886 & $* * 1.018$ \\
\hline Previous relationships (PR) & & & ${ }^{*} 0.626$ & -0.107 & ${ }^{* *} 0.775$ \\
\hline Regulatory quality (RQ) & & & *-0.580 & -0.816 & ${ }^{*}-0.581$ \\
\hline LBXER & & & & 0.186 & \\
\hline LBXPR & & & & -1.075 & \\
\hline LBXRQ & & & & -0.357 & \\
\hline Constant & ${ }^{*}-42.593$ & *-47.045 & *-60.651 & ${ }^{* *}-56.837$ & $* *-71.016$ \\
\hline Model likelihood & 282.105 & 233.883 & 229.102 & 226.634 & 222.289 \\
\hline Nagelkerke $\mathrm{R}^{2}$ & 0.117 & 0.234 & 0.279 & 0.292 & 0.303 \\
\hline Overall \% correct & $62.4 \%$ & $65.3 \%$ & $69.8 \%$ & $69.3 \%$ & $70.6 \%$ \\
\hline $\mathrm{N}$ & 218 & 196 & 199 & 199 & 197 \\
\hline
\end{tabular}

${ }^{*} p<0.10 ;{ }^{* *} p<0.05 ;{ }^{* * *} p<0.01$.

a Large-sized company was redundant. ${ }^{\mathrm{b}} \mathrm{This}$ model excludes the two outliers.

the $p$-values are under 0.10 . Detailed information about Model 3 is reported in Table 2.

Data shown in Table 2 indicate that a corporation which agrees that electoral donations are a Legal bribe is almost three times more likely to be a donor corporation than a non-donor corporation. The confidence interval suggests that the difference could be as little as 1.6 times more likely or as much as 6.3 times more likely. One could argue that electoral donations denoted as 'legal bribes' are not an isolated practice, but are part of a larger context where it is possible that illegal mechanisms are also used to achieve influence with incumbents. This implies, for example, that companies give campaign contributions as well as bribes to political leaders and/or public officials. In the literature, the use of simultaneous legal and illegal mechanisms by private companies has not been recognized explicitly. Harstad and Svensson (2011) suggested that in developing countries electoral donations are bribes of sorts, but while this can be read as saying that the exchange of legal and illegal mechanisms occurs simultaneously, it was not spelled

Table 2: Logistic Regression on the Nature of Electoral Donations in Colombia

\begin{tabular}{|c|c|c|c|c|c|c|c|c|}
\hline \multirow{2}{*}{ Independent variables } & \multirow{2}{*}{ B } & \multirow{2}{*}{ S.E. } & \multirow{2}{*}{ Wald } & \multirow{2}{*}{ DF } & \multirow{2}{*}{ Sig. } & \multirow{2}{*}{$\operatorname{Exp}(B)$} & \multicolumn{2}{|c|}{$95 \%$ C.I. for $\operatorname{Exp}(B)$} \\
\hline & & & & & & & Lower & Upper \\
\hline Age of the company & 0.030 & 0.010 & 8.435 & 1 & 0.004 & 1.030 & 1.010 & 1.051 \\
\hline Medium-sized company & 1.122 & 0.362 & 9.597 & 1 & 0.002 & 3.070 & 1.510 & 6.241 \\
\hline Legal bribe & 1.160 & 0.349 & 11.060 & 1 & 0.001 & 3.192 & 1.611 & 6.324 \\
\hline Expected reciprocity & 0.804 & 0.463 & 3.018 & 1 & 0.082 & 2.234 & 0.902 & 5.532 \\
\hline Previous relationships & 0.626 & 0.370 & 2.866 & 1 & 0.090 & 1.871 & 0.906 & 3.863 \\
\hline Regulatory quality & -0.580 & 0.328 & 3.126 & 1 & 0.077 & 0.560 & 0.295 & 1.065 \\
\hline Constant & -60.651 & 20.548 & 8.712 & 1 & 0.003 & 0.000 & & \\
\hline
\end{tabular}


out. Moreover, this approach has been used by scholars as a single (illegal) phenomenon (Bennedsen et al. 2011; Campos and Giovannoni 2007).

\section{Robustness}

In this section I address potential problems of multicollinearity and interaction between the independent variables as well as the existence of influential points.

I first deal with the multicollinearity issue. I examined the data using an OLS regression, having as dependent variable Age of the company, and as independent variables those obtained in Model 3, including Status. The decision to use Age of the company as dependent variable was taken, having considered that this was the only continuous variable used in the model. The remaining variables, including Status, are binary. Results in Table $\mathbf{3}$ show that, first, the tolerance level of the independent variables is superior to 0.1 , which means that the standard errors of the regression coefficients are not inflated. Therefore, multicollinearity is not an issue. Second, the variance inflation factors are inferior to the threshold of 2, which indicates that there is no multicollinearity problem between the independent variables.

Now, I move on to evaluate the potential interaction of the variables studied. In Table 1, Model 4, I introduced three interaction terms between the variables used to explain electoral donations as bribery (Expected reciprocity, Previous relationships and Regulatory quality) and the variable Legal bribe (LBXER, LBXPR, LBXRQ). In this case the results obtained show no evidence of interaction between these variables, indicating that the interactions are not sufficient to alter the point and estimate intervals of the main effects. These results indicate that Model 3 is, for the moment, robust.
Finally, I assessed the impact that outliers have on Model 3 by analyzing the plots of the residuals. I used two plots: (1) the predicted probability in relation to the change in deviance and (2) the predicted probability in relation to the Cook's influence to identify cases that are poorly fit by the model-the graphics are not shown but are available upon request. In the case of the predicted probability and change in deviance both axes perform the expected ascending and descending tendencies, respectively, indicating that there are nondefaulters with large probabilities of poor fit in the model. However, the plot of the predicted probability and the Cook's distances indicates the possible presence of two outliers: surveys 139 and 174. I examined the data reported in these surveys and found that survey 139 corresponds to one company created in 1982, which currently has 3 employees, and survey 174 corresponds to one company created in 1939, which reported 400 employees. These data were verified and appear to be correct; however, I decide to test the effects of these surveys on the model. In Model 5 gives the model with the two outliers omitted. The beta coefficients and $p$-values of the variables included in Model 5 do not change significantly; they remain similar to those reported in Model 3. The fit of the regression was slightly increased. As it is not possible to establish the reason for the outliers' behavior, beyond the year of creation and the size of the company, the exclusion of these cases can be questioned because of the lack of evidence of unusual behavior or reporting errors. Therefore, I decided to retain the outliers in the analysis. In sum, considering that the influential points do not alter the results reported in the model obtained, Model 3 should be considered the final model.

\section{DISCUSSION}

Becker (1968) argued that law-abiding behavior cannot be taken for granted; however, this does not

Table 3: Collinearity Statistics

\begin{tabular}{|c|c|c|}
\hline Variables & Tolerance & Variance inflation factor \\
\hline \hline Status & 0.827 & 1.209 \\
\hline Medium-sized company & 0.909 & 1.100 \\
\hline Legal bribe & 0.876 & 1.141 \\
\hline Expected reciprocity & 0.952 & 1.050 \\
\hline Previous relationships & 0.967 & 1.034 \\
\hline Regulatory quality & 0.905 & 1.105 \\
\hline
\end{tabular}

Note: Coefficients from ordinary least squares regression. Dependent variable Age of the company. 
exclude the possibility that law-abiding citizens might also break the law. So, do the 'law-abiding' donors abide by the law? The answer is 'perhaps'. Companies have specific goals, and they use electoral donations as a means to an end. Furthermore, they know they will not be punished, because the legal system cannot easily detect or track this kind of compensation. McBarnet termed this kind of justification of deviant behavior 'legal neutralization', because deviant players act legally, but they violate the law. For McBarnet (2006), the successful manipulation of the law effectively blocks any chance of proving behavior to be illegal, and all that is left is to recognize the cleverness and the mastery of legal detail. As Haller and Shore (2005: 12) put it, donors know how the system worksand how to work it. According to Sykes and Matza ([1956] 1996: 209), in the presence of law-abiding behavior, crime can emerge because of neutralization: deviant behaviors represent an apologetic failure of the institutional system, which appears in the first instance as a qualified guide for action, although in reality, it is not. This implies that the deviant actor is not necessarily opposed to the legal system, but uses the weakness of the system to his or her own ends.

Denoting electoral donations as a criminal offensebecause of the undue delivery of influence-is a complex issue that refers to the artificial dichotomies of behavior introduced by the law to dilute legal responsibility. According to Nelken and Levi:

Law may often be part of the problem of corruption... Law may encourage corruption by setting artificially low limits to political expenses.... [E]ven a generous limit will be insufficient to combat the anomic pressure of political competitions where the gains from access to power and the possibility of rewriting the law normally far outweigh the legal penalties or the loss of legitimacy.... Legal campaigns upset predictability, and law can express an over-ambitious ideal of the relationship between citizens and the State. (1996: 9)

The information collected here shows that companies in Colombia use electoral donations as a kind of bribe to achieve their aims, as suggested by Harstad and Svensson in the case of developing countries. If elections in Colombia cannot be completely funded with public resources, then there is need of a strong electoral system that guarantees that donors will not receive delayed compensations for their electoral contributions. The challenge is how to strengthen the institutional capacity of the government and the society to neutralize those electoral donors who seek to divert political decisions. However, I believe that this is not enough. Political candidates should be accountable not only for their behavior in office but also for the money received while campaigning. Without a sincere commitment by the electoral authorities and the political candidates/incumbents to promote transparency, the private funding of elections in Colombia will remain as a 'legal bribe'. Admittedly, this is a complex problem.

This article has focused on studying the relationships between electoral donors and the characterization of electoral financing mechanisms, but has left some issues intentionally unattended, because they did not correspond to the core analysis of the article. Does the size of the electoral donations matter in achieving influence? Have electoral donations more effectiveness in terms of impact on policy outcomes than bribery? The list of questions can surely be extended. These issues will be the focus of additional analysis in the future.

\section{CONCLUSIONS}

Nearly a decade ago Maguire (2002: 368) observed, 'The last twenty or so years have seen a 'data explosion' in the crime field.' This statement is not entirely true in the case of political corruption. Data on corruption are usually collected as a side product in surveys on economic and political issues. International organizations and risk-rating agencies in particular have conducted this type of fieldwork on the company and country levels. One contribution this article makes is to collate a unique data set on political corruption on the company level. The data collection strategy includes a number of considerations regarding the profile of the informants and the scales employed to collect the information, and a series of quality control measurements to enhance data reliability.

In this article I study why companies made electoral donations to support political leaders during the 20062007 electoral campaigns in Colombia. I use as analytical framework the contributions on bribe theory by Harstad and Svensson (2011) and Lambsdorff (2008). The logic behind the selection of this approach is simple: if electoral donations are seen as 'legal bribes', then bribe theory should be capable of explaining why companies are prepared to pay. 
The results show that for the surveyed companies electoral donations are seen as 'legal bribes'. The donor companies, mostly middle-sized and old companies, pay because they consider electoral regulations to be weak, they have pre-existing relationships with political leaders, and they expect reciprocity from incumbents. These results amount to a typical case of what McBarnet calls 'law neutralization'. Offenders benefit from a legitimate action that guarantees protection from prosecution for their crimes. This revealing evidence has immense significance for policy design. It points to the importance of strengthening institutional controls to make candidates accountable for the money they receive to fund election campaigns.

\section{ACKNOWLEDGEMENTS}

I wish to thank Humberto de la Calle, Felipe Estrada, Janne Flyghed, Lars Korsell, Viviana Stechina, Jakob Svensson, the Nordic Group on Corruption, seminar participants at Stockholm University, and the anonymous referees of this journal for comments on earlier versions of the manuscript.

\section{FUNDING}

The research for this article was supported by the Swedish International Development Cooperation Agency (project SWE-2007-209).

\section{APPENDIX}

\section{Appendix A: Companies Replaced During Fieldwork, by Size and Reason}

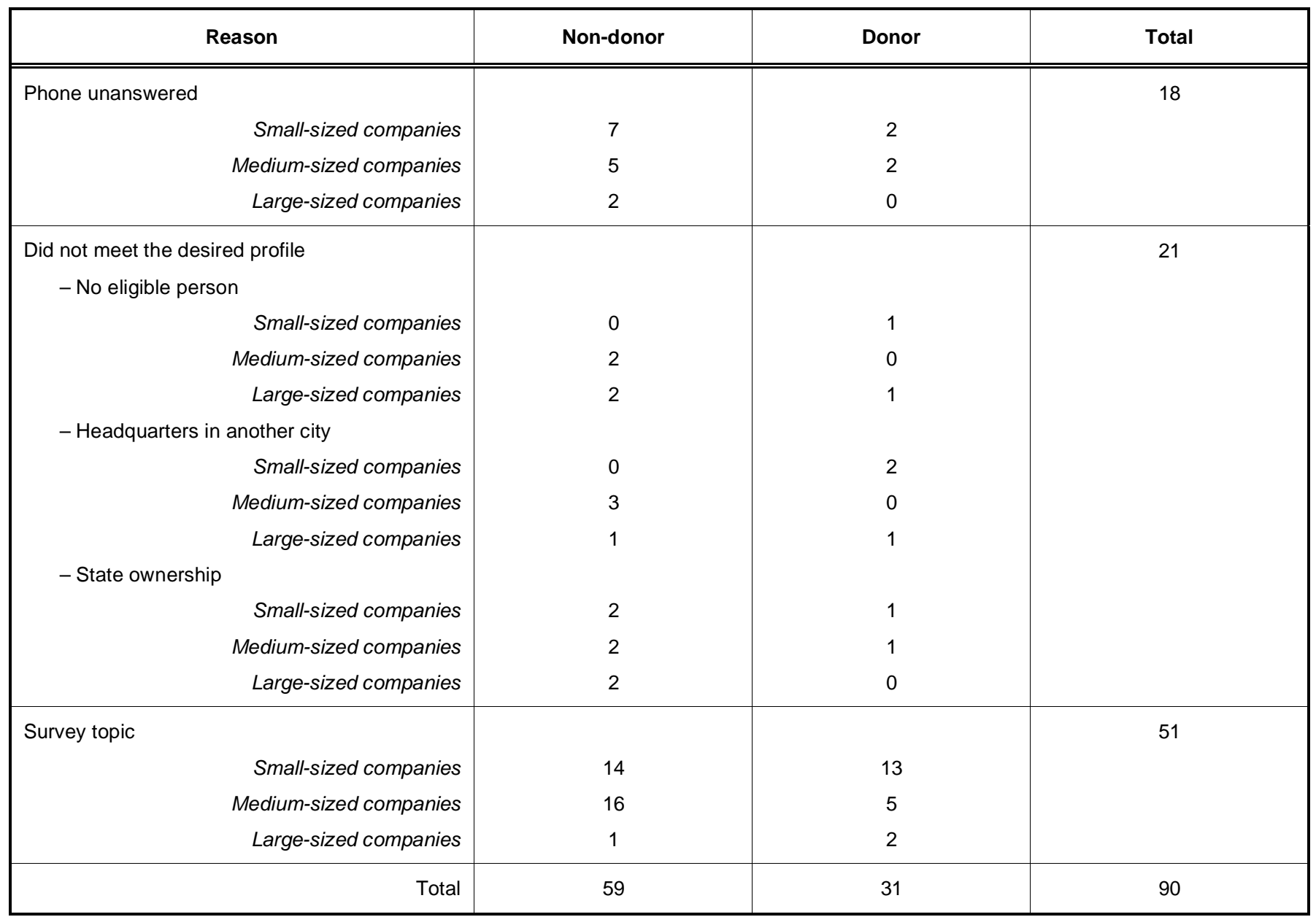




\section{Appendix B: Breakdown of Companies Replaced During Fieldwork, with Unreplaced Companies for Comparison}

\begin{tabular}{|c|c|}
\hline Explanatory variables & $\begin{array}{l}\text { Company size } \\
\qquad[N=218]\end{array}$ \\
\hline Unreplaced companies & $\begin{array}{c}-100.467 \\
(104.166) \\
{[0.336]}\end{array}$ \\
\hline $\begin{array}{c}\text { Companies replaced because: } \\
\text { - Phone unanswered }\end{array}$ & $\begin{array}{c}-27.419 \\
(189.242) \\
{[0.885]}\end{array}$ \\
\hline - No eligible person & $\begin{array}{c}-139.268 \\
(447.042) \\
{[0.756]}\end{array}$ \\
\hline - Headquarters in another city & $\begin{array}{c}-62.118 \\
(295.431) \\
{[0.834]}\end{array}$ \\
\hline - State ownership & $\begin{array}{c}-32.327 \\
(277.027) \\
{[0.907]}\end{array}$ \\
\hline - Survey topic & $\begin{array}{c}-121.779 \\
(121.947) \\
{[0.319]}\end{array}$ \\
\hline
\end{tabular}

Note: Explanatory variables in the left-hand column reported as dummy variables take the value 1 if the company was replaced; otherwise, 0 . Each cell gives the beta coefficient from ordinary least squares regressions, standard errors in parentheses, and p-values in square brackets. Dependent variable Company size before dummy recodification.

\section{Appendix C: $\quad$ List of Variables}

\begin{tabular}{|c|c|c|}
\hline Variables & Description & Scale used in the model \\
\hline Status & $\begin{array}{l}\text { Have the company made donations to political campaigns in the } \\
\text { last election period (2006-2007) }\end{array}$ & $\begin{array}{l}1=\text { Donor, } \\
0=\text { Non donor }\end{array}$ \\
\hline Age of the company & In what year did this company begin to operate & \\
\hline Company size & How many full time employees does this company employ? & $\begin{array}{l}\text { Small-sized } 1=1-49 ; 0=\text { Otherwise } \\
\text { Medium-sized } 1=50-249 ; 0=\text { Otherwise } \\
\text { Large-sized } 1 \geq 250 ; 0=\text { Otherwise }\end{array}$ \\
\hline Bribe substitute & $\begin{array}{l}\text { If a company like yours decides not to make donations to political } \\
\text { campaigns, do you believe that this company would instead give } \\
\text { unofficial payments or bribes to public officials? }\end{array}$ & $\begin{array}{l}1=\text { Yes, } \\
0=\text { Otherwise }\end{array}$ \\
\hline Legal bribe & $\begin{array}{l}\text { How much do you agree or disagree with the following } \\
\text { statements? 'Donations to political campaigns are a form of } \\
\text { bribery.' }\end{array}$ & $\begin{array}{l}0=\text { Strongly disagree, disagree and undecided } \\
1=\text { Agree and strongly agree }\end{array}$ \\
\hline Additional cost & $\begin{array}{l}\text { 'Donations to political campaigns generate additional costs for } \\
\text { companies.' }\end{array}$ & Same as above \\
\hline Expected reciprocity & $\begin{array}{l}\text { 'Donations to political campaigns are used by private companies } \\
\text { to obtain particular benefits.' }\end{array}$ & Same as above \\
\hline Previous relationships & $\begin{array}{l}\text { Has the head of the company previously worked in the public } \\
\text { sector or been part of an ad hoc government group, or has the } \\
\text { company head contributed financially to the election campaign of } \\
\text { relatives or candidates with the same political ideology? }\end{array}$ & $\begin{array}{l}1=\text { Yes, } \\
0=\text { Otherwise }\end{array}$ \\
\hline Regulatory quality & $\begin{array}{l}\text { What is your perception of the quality of the following process in } \\
\text { public institutions in Colombia? 'Financing of electoral } \\
\text { campaigns.' Please evaluate quality in terms of openness, clarity, } \\
\text { and accountability in the process. }\end{array}$ & $\begin{array}{l}0=\text { Very low, low and acceptable quality } \\
1=\text { High and very high quality }\end{array}$ \\
\hline
\end{tabular}




\section{Appendix D: $\quad$ Logistic Regression Using Alternative Dichotomous Variables}

\begin{tabular}{|c|c|c|c|c|c|}
\hline \multirow{2}{*}{\multicolumn{2}{|c|}{ Variables }} & \multicolumn{2}{|c|}{ Alternative 1} & \multicolumn{2}{|c|}{ Alternative 2} \\
\hline & & 0 & 1 & 0 & 1 \\
\hline Legal bribe & $\begin{array}{c}\text { N } \\
\text { B } \\
\text { S.E. }\end{array}$ & 68 & $\begin{array}{c}127 \\
1.114 \\
0.332\end{array}$ & 103 & $\begin{array}{c}92 \\
1.493 \\
0.349\end{array}$ \\
\hline \multicolumn{2}{|c|}{ Additional cost } & 29 & $\begin{array}{c}166 \\
0.050 \\
0.439\end{array}$ & 74 & $\begin{array}{c}121 \\
0.534 \\
0.323\end{array}$ \\
\hline \multicolumn{2}{|c|}{ Expected reciprocity } & 30 & $\begin{array}{c}165 \\
0.390 \\
0.440\end{array}$ & 65 & $\begin{array}{c}130 \\
-0.334 \\
0.362\end{array}$ \\
\hline \multicolumn{2}{|c|}{ Regulatory quality } & 107 & $\begin{array}{c}88 \\
-0.625 \\
0.312\end{array}$ & 181 & $\begin{array}{c}14 \\
0.166 \\
0.598\end{array}$ \\
\hline \multicolumn{2}{|c|}{ Nagelkerke $\mathrm{R}^{2}$} & \multicolumn{2}{|c|}{0.143} & \multicolumn{2}{|c|}{0.172} \\
\hline \multicolumn{2}{|c|}{ Overall \% correct } & \multicolumn{2}{|c|}{$63.6 \%$} & \multicolumn{2}{|c|}{$67.2 \%$} \\
\hline
\end{tabular}

Note: Alternative 1 recodes as 0 answers in categories 1 and 2 , and as 1 answers in categories 3 , 4, and 5 , where 1 means agreement with the concept. Alternative 2 recodes as 0 answers in categories 1,2, and 3, and as 1 answers in categories 4 and 5 , where 1 means agreement with the concept. Each cell gives number of observations, beta coefficients from logistic regressions and standard errors. Dependent variable Status. The lower category was used as reference.

\section{Appendix E: Descriptive Statistics and Frequencies Observed}

\begin{tabular}{|c|c|c|c|c|c|}
\hline \multirow{2}{*}{ Variables } & \multicolumn{3}{|c|}{ Descriptive Statistics } & \multicolumn{2}{c|}{ Frequencies observed } \\
\cline { 2 - 6 } & Mean & SD & N & Yes & 8 \\
\hline \hline Bribe substitute & 0.0396 & 0.1955 & 202 & 194 \\
\hline Legal Bribe & 0.6355 & 0.4824 & 213 & 179 & 34 \\
\hline Additional cost & 0.8404 & 0.3671 & 212 & 177 & 161 \\
\hline Expected reciprocity & 0.8349 & 0.3721 & 218 & 57 \\
\hline Previous relationships & 0.7385 & 0.4404 & 204 & 92 & 112 \\
\hline Regulatory quality & 0.4510 & 0.4988 & & 92 \\
\hline
\end{tabular}

\section{Appendix F: $\quad$ Pair-Wise Correlation Coefficients}

\begin{tabular}{|c|c|c|c|c|c|c|c|}
\hline Variables & $\begin{array}{c}\text { Age of } \\
\text { company }\end{array}$ & $\begin{array}{l}\text { Medium } \\
\text { company }\end{array}$ & $\begin{array}{c}\text { Bribe } \\
\text { substit. }\end{array}$ & Legal bribe & $\begin{array}{l}\text { Add. } \\
\text { cost }\end{array}$ & $\begin{array}{c}\text { Expect. } \\
\text { recip. }\end{array}$ & $\begin{array}{l}\text { Previous } \\
\text { relation. }\end{array}$ \\
\hline Medium-sized company & -0.124 & & & & & & \\
\hline Bribe substitute & 0.104 & -0.033 & & & & & \\
\hline Legal bribe & -0.055 & 0.079 & 0.024 & & & & \\
\hline Additional cost & -0.018 & -0.114 & 0.010 & 0.153 & & & \\
\hline Expected reciprocity & 0.026 & -0.135 & 0.088 & 0.117 & 0.227 & & \\
\hline Previous relationships & 0.054 & 0.113 & 0.062 & 0.035 & 0.118 & -0.036 & \\
\hline Regulatory quality & 0.100 & -0.040 & 0.020 & -0.253 & -0.122 & -0.131 & 0.055 \\
\hline
\end{tabular}

\section{REFERENCES}

ACE. 2009. Comparative Data: Parties and Candidates. Retrieved 2 September, 2011 (http: //aceproject.org/epic-en/pc).

Apollonio, D.E. and Raymond La Raja. 2004. "Who Gave Soft Money? The Effect of Interest Group Resources on Political Contributions." Journal of Politics 66(4): 1134-1154. http://dx.doi.org/10.1111/j.0022-3816.2004.00293.x
Austen-Smith, David. 1998. "Allocating Access for Information and Contributions." Journal of Law, Economics, and Organization 14(2): 277-303.

http://dx.doi.org/10.1093/jleo/14.2.277

Azfar, Oman and Peter Murrell. 2009. "Identifying Reticent Respondents: Assessing the Quality of Survey Data on Corruption and Values." Economic Development and Cultural Change 57(2): 387-411.

http://dx.doi.org/10.1086/592840 
Ball, Richard. 1995. "Political Lobbying as Welfare-Improving Signaling." Economics and Politics 7(2): 119-146. http://dx.doi.org/10.1111/j.1468-0343.1995.tb00107.x

Becker, Gary. 1968. "Crime and Punishment: An Economic Approach." Journal of Political Economy 76(2): 169-217. http://dx.doi.org/10.1086/259394

Bennedsen, Morten, Sven Feldmann and David Lassen. 2011. "Strong Companies Lobby, Weak Companies Bribe. A Survey-based Analysis of the Demand for Influence and Corruption." CESifo Working Paper Series 3496.

Campos, Nauro and Francesco Giovannoni. 2007. "Lobbying, Corruption and Political Influence." Public Choice 131(1/2): 121. http://dx.doi.org/10.1007/s11127-006-9102-4

Clausen, Bianca, Aart Kraay and Peter Murrell. 2011. "Does Respondent Reticence Affect the Results of Corruption Surveys? Evidence from the World Bank Enterprise Survey for Nigeria." Pp. 428-450 International Handbook of the Economics of Corruption. Vol. 2, edited by S. RoseAckerman and T. Søreide. London: Edward Elgar.

Deas, Malcolm. 1993. Del Poder y la Gramática: Y Otros Ensayos sobre Historia, Política y Literatura Colombianas. Bogotá: Tercer Mundo Editores.

Della Porta, Donatella and Alberto Vannucci. 1999. Corrupt Exchanges. New York: Aldine de Gruyter.

Departamento Nacional de Planeación. 2009. Indicadores Económicos. Bogotá: Imprenta Nacional.

Friedrichs, David. 2004. Trusted Criminals. White-Collar Crime in Contemporary Society. Belmont: Wadsworth/Thomson Learning.

Gordon, Stacy. 2001. "All Votes Are not Created Equal: Campaign Contributions and Critical Votes." Journal of Politics 63(1): 249-269. http://dx.doi.org/10.1111/0022-3816.00067

Grossman, Gene and Elhanan Helpman. 1994. "Protection for Sale." American Economic Review 84(4): 833-850.

Hall, Richard and Alan Deardorff. 2006. "Lobbying as Legislative Subsidy." American Political Science Review 100(1): 69-84. http://dx.doi.org/10.1017/S0003055406062010

Haller, Dieter and Cris Shore. 2005. "Sharp Practice: Anthropology and the Study of Corruption." Pp. 1-26 in Corruption: Anthropological Perspectives, edited by D. Haller, and C. Shore. London: Pluto Press.

Harstad, Bård and Jakob Svensson. 2011. "Bribes, Lobbying and Development." American Political Science Review 105(1): 46-63.

http://dx.doi.org/10.1017/S0003055410000523

Hart, David. 2001. "Why Do Some Firms Give? Why Do Some Give a Lot? High-tech PACs, 1977-1996." Journal of Politics 63(4): 1230-1249. http://dx.doi.org/10.1111/0022-3816.00108

Hersch, Philip and Gerald McDougall. 2000. "Determinants of Automobile PAC Contributions to House Incumbents: Own versus Rival Effects." Public Choice 104(3/4): 329-343. http://dx.doi.org/10.1023/A:1005179819347

Hosmer, David and Stanley Lemeshow. 2002. Applied Logistic Regression. 2nd ed. New York: Wiley.

Lambsdorff, Johann. 2008. The Institutional Economics of Corruption and Reform. Theory, Evidence and Policy. Cambridge: Cambridge University Press.
Lensvelt-Mulders, Joop Hox, Peter van der Heijden and Cora Maas. 2005. "Meta-Analysis of Randomized Response Research: Thirty-five Years of Validation." Sociological Methods \& Research 33(3): 319-348.

http://dx.doi.org/10.1177/0049124104268664

Lohmann, Susanne. 1985. "Information, Access and Contributions." Public Choice 58(3/4): 267-284.

Maguire, Mike. 2002. "Crime Statistics: The Data Explosion and Its Implications." Pp. 322-375 in The Oxford Handbook of Criminology, edited by M. Maguire, R. Morgan and R. Reiner. Oxford: Oxford University Press.

McBarnet, Doreen. 2006. "After Enron Will 'Whiter than White Collar Crime' Still Wash?" British Journal of Criminology 46(6): 1091-1109. http://dx.doi.org/10.1093/bjc/azl068

Nassmacher, Karl-Heinz. 2003. "Political Parties, Funding and Democracy." Pp. 1-19 in Funding Political Parties and Electoral Campaigns, edited by $\mathrm{A}$. Reginald and $\mathrm{M}$. Tjerbström: Stockholm: Trydells Tryckeri.

Rose-Ackerman, Susan. 1975. "The Economics of Corruption." Journal of Public Economics 1975(4): 187-203. http://dx.doi.org/10.1016/0047-2727(75)90017-1

Rose-Ackerman, Susan. 1999. Corruption and Government: Causes, Consequences and Reform. Cambridge: Cambridge University Press. http://dx.doi.org/10.1017/CBO9781139175098

Smith, Richard. 1995. "Interest Group Influence in the US Congress." Legislative Studies Quarterly 20(1): 89-139. http://dx.doi.org/10.2307/440151

Stratmann, Thomas. 1992. "Are Contributors Rational? Untangling Strategies of Political Action Committees." Journal of Political Economy 100(3): 647-664. http://dx.doi.org/10.1086/261833

Stratmann, Thomas. 1998. "The Market for Congressional Votes: Is Timing of Contributions Everything?" Journal of Law and Economics 41(1): 85-113. http://dx.doi.org/10.1086/467385

Stratmann, Thomas. 2005. "Some Talk: Money in Politics. A (Partial) Review of the Literature." Public Choice 124(1/2): 135-156. http://dx.doi.org/10.1007/s11127-005-4750-3

Sung, Hung-En. 2004. "Democracy and Political Corruption: A Crossnational Comparison." Crime, Law and Social Change 41(2): 179-194. http://dx.doi.org/10.1023/B:CRIS.0000016225.75792.02

Svensson, Jakob. 2003. "Who Must Pay Bribes and How Much?" Quarterly Journal of Economics 118(1): 207-230. http://dx.doi.org/10.1162/00335530360535180

Sykes, Gresham and David. [1956] 1996. "Techniques of Neutralization." Pp. 206-213 in Criminological Perspectives: A Reader, edited by J. Muncie, E. McLaughlin and M. Langan. London: Sage.

Treisman, Daniel. 2000. "The Causes of Corruption: A CrossNational Study." Journal of Public Economics 76(3): 399-457. http://dx.doi.org/10.1016/S0047-2727(99)00092-4

World Economic Forum. 2006. The Global Competitiveness Report 2006-2007. New York: Oxford University Press.

Zullo, Roland. 2006. "Public-Private Contracting and Political Reciprocity." Political Research Quarterly 59(2): 273-281. http://dx.doi.org/10.1177/106591290605900209

Received on 22-06-2012

Accepted on 05-11-2012

Published on 13-11-2012

DOI: http://dx.doi.org/10.6000/1929-4409.2012.01.16

(C) 2012 Nubia Evertsson; Licensee Lifescience Global.

This is an open access article licensed under the terms of the Creative Commons Attribution Non-Commercial License (http://creativecommons.org/licenses/by-nc/3.0/) which permits unrestricted, non-commercial use, distribution and reproduction in any medium, provided the work is properly cited. 